Original Article

\title{
LOTMARIA PASSIM AS THIRD PARASITE GASTROINTESTINAL TRACT OF HONEY BEES LIVING IN TREE TRUNK
}

\author{
Maria Michalczyk ${ }^{1^{*}}$ \\ Agata Bancerz-Kisiel² \\ Rajmund Sokół ${ }^{1}$ \\ 'Departament of Parasitology and Invasive Diseases, Faculty of Veterinary \\ Medicine, University of Warmia and Mazury in Olsztyn, Poland \\ 2University of Warmia and Mazury in Olsztyn, Faculty of Veterinary Medicine, \\ Department of Epizootiology, Oczapowski 13 Street, 10-718 Olsztyn, Poland \\ *corresponding author: maria.michalczyk@uwm.edu.pl \\ Received: 15 November 2019; accepted: 01 April 2020
}

Abstract

Honey bees (Apis mellifera L.) inhabiting trees in forests are not managed by humans or treated for pathogens; therefore, many researchers and beekeepers believe that viral, bacterial, and parasitic diseases may lead to their decline. The aim of the study was to evaluate the prevalence of $L$. passim and Nosema spp. in feral colonies by real-time PCR. This study was performed on twenty-six samples of honey bees inhabiting tree trunks in north-eastern Poland. One sample consisted of sixty worker bee abdomens collected from hollow trees. Honey bees were sampled only from naturally colonized sites. Amplicons of the three evaluated pathogens were detected in twenty of the twenty-six tested samples. A significant correlation was observed between infection with three pathogens ( $N$. apis, $N$. ceranae, L. passim) $(r=0.84)$ compared to infection with only two pathogens ( $N$. apis and $N$. ceranae) $(r=0.49)$. $N$. ceranae was the predominant pathogen, but infections with various severity caused by $L$. passim were also noted in fourteen of the twenty-six tested samples. In view of the general scarcity of epidemiological data concerning coinfections with Nosema spp. and $L$. passim in honey bees in tree trunks in other countries, further research is needed to confirm the effect of concurrent pathogenic infections on the decline of bee colonies.

Keywords: co-parasitism, Lotmaria passim, Nosema apis, Nosema ceranae, real-time PCR, tree trunks

\section{INTRODUCTION}

Honey bees (Apis mellifera L.) initially colonized deciduous forests and trees that offered shelter as well as pollen and nectar for sustenance (Ruttner, 1988; Crane, 1999), but their habitats gradually moved from forests to human settlements (Crane, 1999; Banaszak, 2009). Bee habitats were also transformed by forest clearing (De la Rua et al., 2009, Potts et al., 2010). Nevertheless, feral honey bees still colonize tree trunks and log hives world, including Poland (Seeley, 2007; Oleksa, Gawroński, \& Tofilski, 2013; Ilyasov et al., 2015) ог аге specially introduced to preserve biodiversity. These bees are not managed by humans or treated for pathogens, and therefore many researchers and beekeepers believe that viral, bacterial, and parasitic diseases may lead to their decline (Sammataro, Gerson, \& Needham, 2000; Moritz et al., 2010; Neumann \& Carreck, 2010; Rosenkranz, Aumeier, \& Ziegelmann, 2010; Martin et al., 2012; van Dooremalen et al., 2012). However, not only feral honey bees are threatened with extinction, and despite high beekeeping standards and veterinary care, apiaries around the world have also been experiencing a collapse of bee colonies. The agricultural sector has sustained massive losses due to the decline of feral bees and honeybees, which play an important role in the preservation of biological diversity and sustainable farming (De la Rua et al., 2009; Moritz et al., 2010). Bees are among the most effective pollinators of entomophilous plants around the world, and the high quality of crops pollinated by bees generates environmental and economic benefits. For these reasons, 
considerable research has been devoted to bee health and factors that influence the vitality and performance of honey bee colonies (Neumann \& Carreck, 2010; Potts et al., 2010; Goulson et al., 2015; Ptaszyńska et al., 2018). Varroa destructor is regarded to be the most harmful parasite limiting bee colonies and capable of transmitting bee viruses (Rosenkranz, Aumeier, \& Ziegelmann, 2010; Borsuk et al., 2012; Stanimirovic et al., 2017). Other bee pathogens are also increasingly being identified, including viruses (DWV, ABPV, CBPV), bacteria (Paenibacillus larvae, Melissococcus pluton), pathogenic fungi (Nosema apis and Nosema cerane), and protozoa of the family Trypanosomatidae (Sokól et al., 2016; Nazzi \& Le Conte, 2016; Stevanovic et al., 2016; ŁopieńskaBiernat et al, 2017; Michalczyk et al., 2018).

Trypanosomatidae are unicellular flagellates and obligatory parasites infecting various host mammals, insects and plants (Barret et al., 2003). These protozoa are generally found in the host's intestines (Maslov et al., 2013). They have been detected in insects of the order Hymenoptera and in bumblebees (Schlunsch et al., 2010). Honeybees are infected mostly by the Crithidia mellificae and Lotmaria passim species of the family Trypanosomatidae: (Langridge \& McGhee, 1967; van Engelsdrop et al., 2009; Cornman et al., 2012; Ravoet et al., 2013; Schwarz, 2014; Arismendi et al., 2016). At present, L. passim is the predominant pathogenic protozoan species in the world (Schwarz et al., 2015). These protozoa have been widely investigated due to their detrimental effect on bees' behavior, physiology and immune function (Gegear et al., 2005; Runckel et al., 2011; Ravoet et al., 2013; Evans \& Schwarz, 2013). Recently, increasing attention has been paid on infections caused by Trypanosomatidae and microsporidian parasites of the genus Nosema (Stevanovic et al., 2016; Hubert et al., 2017; Tritschler et al., 2017).

$N$. apis and $N$. ceranae microsporidia are highly specialized unicellular eukaryotic parasites (Adl et al., 2005). These pathogens are responsible for nosemosis, one of the most widespread bee diseases in the world. Bees are infected by spores ingested with water or pollen (Webster et al., 2004; Chen et al., 2008). The spread of nosemosis is largely influenced by weather conditions in different seasons of the year. Sulborska et al. (2019) have reported that Nosemaspp. are transmitted with the wind. $N$. ceranae is regarded as the most ubiquitous endoparasite of honey bees, but $N$. apis is also frequently encountered in Poland and in the world (Fries, 2010; Higes et al., 2013). However, the infection dynamics and the interactions between Nosema spp. and L. passim in honey bees inhabiting tree trunks and log hives have never been investigated. This study is the first attempt in both Poland and the world to determine the severity of infections caused by Nosema spp. and L. passim in tree trunks. In this study we aimed to evaluate the prevalence of Nosema spp. and L. passim in bee inhabiting tree trunks by real-time PCR and determine relationships in the occurrence of these pathogens.

\section{MATERIAL AND METHODS}

\section{Bee samples}

The study was performed on twenty-six samples of bees (colonies) collected from tree trunks in north-eastern Poland $\left(21^{\circ} 04^{\prime} 0^{\prime \prime}-21^{\circ} 41^{\prime} 0 " E\right.$ and $53^{\circ} 09^{\prime} 0^{\prime \prime}-53^{\circ} 29^{\prime} 0^{\prime \prime} N$ ). Feral honey bees were sampled only from naturally colonized sites. No clinical disease symptoms like diarrhea, inability to fly, paralysis, gathering in small groups, dead bees on the bottom of the hive with swollen abdomen and legs retracted below the chest, or reduced activity were observed in these colonies. The experiment involved colonies with a life span of at least three seasons, during which the insects were monitored. Workers were sampled from every colony with the use of an open 0.9 I jar that was placed under the exit hole in a hollow tree. When bees entered the jar, the jar was capped, transported to the laboratory and stored at a temperature of $-20^{\circ} \mathrm{C}$.

\section{DNA analysis}

The collected twenty-six samples were analyzed with the use of molecular methods to identify and quantify Nosema spp. and L. passim. Each test was performed on a random sample of sixty worker bee abdomens collected from hollow trees. Whole abdomens of sixty bees per 
sample were homogenized with a homogenizer. The whole homogenate from each sample was taken for DNA extraction. Genomic DNA was isolated with the Genomic MiniKit (A\&A Biotechnology, Gdynia, Polska) according to the manufacturer's instructions. Real-time PCR was conducted with the use of FastStart Essentials

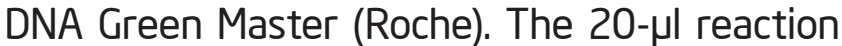
mixture contained ca. $150 \mathrm{ng}$ of isolated DNA $(1 \mu l), 10 \mu$ of FastStart Essential DNA Green Master, and $0.5 \mu \mathrm{l}$ of each primer (with a final concentration of $0.5 \mu \mathrm{M}$ ). It was supplemented to $20 \mu$ with FastStart Essential DNA Green Master Water (PCR grade). The qPCR reaction was carried out in a Light Cycler Nano System thermal cycler (Roche). The reactions were run using a thermal profile consisting of a hold at $95^{\circ} \mathrm{C}$ for $10 \mathrm{~min}$, followed by 40 cycles of a 2-step amplification consisting of $95^{\circ} \mathrm{C}$ for $10 \mathrm{~s}$, primer annealing at $54^{\circ} \mathrm{C}$ for $60 \mathrm{~s}$ and $72^{\circ} \mathrm{C}$ for $15 \mathrm{~s}$, melting at $65^{\circ} \mathrm{C}$ for $60 \mathrm{~s}$ and $95^{\circ} \mathrm{C}$ for $1 \mathrm{~s}$, and a final hold at $45^{\circ} \mathrm{C}$ for $600 \mathrm{~s}$. Lotmaria passim was identified with primers LpCytb_F2: 5'-AGTaTGAGCaGTaGGtTTTaTTATa-3' and LpCytb_R: 5'-gcCAaAcACCaATaACtGGtACt-3 (Vejnovic et al., 2018).

Nosema apis and $N$. ceranae were identified and quantified with FastStart Essentials DNA Green Master (Roche). The 20- $\mu$ reaction mixture contained approximately $150 \mathrm{ng}$ of isolated DNA (l), $10 \mu$ of FastStart Essential DNA Green Master, and $0.5 \mu l$ of each primer. It was supplemented to $20 \mu$ with FastStart Essential DNA Green Master Water (PCR grade). The following primers were applied: 321APIS FOR (5'-GGGGGCATGTCTTTGACGTACTATGTA-3') and 321APIS REV (5'-GGGGGGCGTTTAAAATGTGAAACAACTATG-3') for $N$. apis, and 218 MITOC REV (5'-CCCGGTCATTCTCAAACAAAAAACCG-3') for $N$. ceranae (Martı'n-Hernandez et al. 2007). The reactions were run using a thermal profile consisting of a hold at $95^{\circ} \mathrm{C}$ for $600 \mathrm{~s}$, followed by forty-five cycles of a three-step amplification consisting of $95^{\circ} \mathrm{C}$ for $20 \mathrm{~s}, 55^{\circ} \mathrm{C}$ for $20 \mathrm{~s}$, and $72^{\circ} \mathrm{C}$ for $15 \mathrm{~s}$, melting at $65^{\circ} \mathrm{C}$ for $60 \mathrm{~s}$ and $95^{\circ} \mathrm{C}$ for $1 \mathrm{~s}$, and a final hold at $45^{\circ} \mathrm{C}$ for $600 \mathrm{~s}$. In the real-time PCR assay, L. passim, N. apis and $N$. ceranae parasites were quantified in bees inhabiting tree trunks with the use of DNA standards (University of Belgrade, Faculty of Veterinary Medicine, Department of Biology, Serbia). In each reaction, standard curves were generated by ten-fold serial dilutions of known concentrations of $L$. passim, N. apis, and $N$. ceranae DNA for each parasite separately. Each run contained negative and positive control and experimental samples preformed in duplicates. The gene copy number of L. passim and Nosema spp. were calculated using software program LightCycler Nano (Roche).

\section{Statistical analysis}

The statistical analysis was performed using SAS software Version 9.5 (Statistical Analysis System Institute, Cary, NC). The correlation between the analyzed pathogens was determined through the calculation of Spearman's rank correlation coefficient r. The number of copies of the genome Nosema spp. and $L$. passim identified on the bees were compared using the one-way ANOVA, followed by Tukey test. Differences at $p \leq 0.05$ were considered significant.

\section{RESULTS}

After the examination of twenty-six feral honeybee colonies, we found that $N$. ceranae was the predominant pathogen. The presence of $N$. ceranae was identified in twenty-five samples (96.15\%). N. apis in twenty samples $(76.92 \%)$, L. passim in fourteen samples (53.84\%); both pathogens were always accompanied by N.ceranae. While Nosema ceranae alone was detected in only two cases. Coinfections with $N$. ceranae/L. passim were only noted in three samples (11.5\%), coinfections with N.apis/N.Ceranae in nine samples (34.61\%) and multiple infections with N. ceranae/N.apis/L. passim in eleven samples (42.3\%) (Fig.1). Statistically significant ( $F=25.17$ $p=0.000001)$ variations in the average gene copy number of L. passim and Nosema spp. were observed in the bees (Fig. 2). A significant correlation was observed between infection with the three analyzed pathogens (N.apis, N. ceranae, 


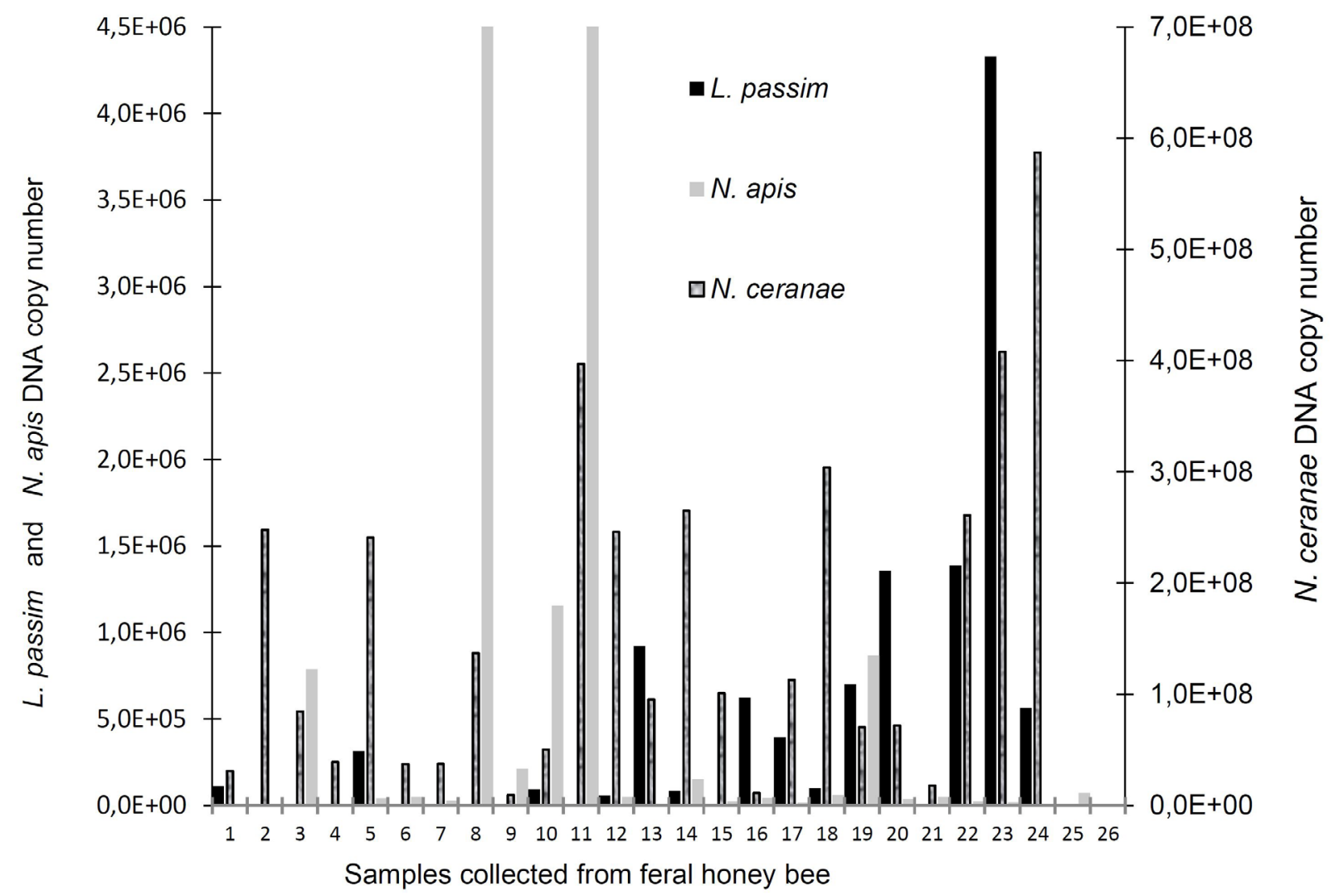

Fig. 1. Severity of infections caused by L. passim and Nosema spp. in bee samples.

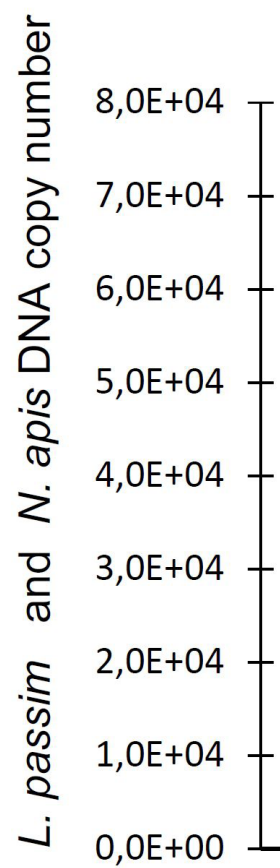

b

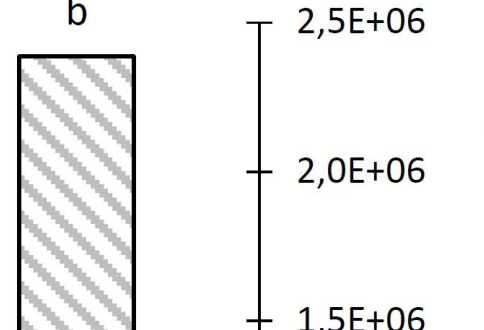

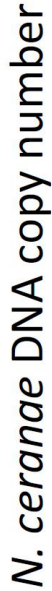

L. passim

N. apis

N. ceranae

Fig. 2. Average number of copies of the genome per bee.

a, $b$ - the different small letters denote statistically significant differences between the number of copies of the genome of Lotmaria passim and Nosema spp. (one-way ANOVA; Tukey test, $\mathrm{p} \leq 0.05$ ) 
L. passim) ( $r=0.84)$ compared to infection with two pathogens only ( $N$. apis and $N$. ceranae) $(r=0.49)$.

\section{DISCUSSION}

Crithidia mellificae (Langridge \& McGhee, 1967) were initially regarded as the most prevalent pathogen of family Trypanosomatidae in honeybee colonies (Ravoet et al., 2013). However, Schwarz et al. (2015) demonstrated that honeybees were most frequently infected by L. passim. Many isolates that had earlier been identified as C. mellificae were reclassified as L. passim, and the latter species is presently regarded as the predominant protozoan species in bees worldwide (Schwarz et al., 2015). In this study, we attempted to evaluate the prevalence of L. passim and Nosema spp. in feral honeybees and to determine potential relationships between the occurrence of these parasites.

As many researchers have demonstrated, L.passim can compromise the health of honeybees, and coinfections with other pathogens can exacerbate colony losses. Tritschler et al. (2017) reported a relationship between the occurrence of Nosema spp. and L. passim in honeybees. Contrary results were reported by Vejnovic et al. (2018), who attributed the observed variations in the prevalence of Nosema spp. and L. passim to different methodological approaches. Vejnovic et al. (2018) studied pooled samples, whereas Tritschler et al. (2017) examined individual bees. Research results are also affected by weather conditions and differences in the prevalence of Nosema spp. in various countries (Sulborska et al., 2019). These pathogens have been identified in $46.7 \%$ of bee colonies in Switzerland (Retschnig et al., 2017) and in $95.7 \%$ of bee colonies in Serbia (Stevanovic et al., 2016).

Bee colonies are also increasingly being infected with $N$. ceranae in Poland, which was confirmed in our previous study (Michalczyk, Sokół, \& Koziatek, 2015). Nosema ceranae was also the predominant pathogen in the feral honeybee samples analyzed in the present study (Fig. 2). Lotmaria passim always co-occurred with
Nosema spp., and considerable differences in the abundance of pathogens were noted between tree trunks. In contrast, Vejnovic et al. (2018) reported no correlation between the occurrence of $N$. ceranae and $L$. passim. In the current study, nearly all monitored colonies were infected with $N$. ceranae, and coinfections with L. passim were additionally observed in fourteen samples. Real-time PCR supported accurate quantification of Nosema sp. and L. passim in the evaluated colonies. Our data presented significantly more cases with L. passim infection with both Nosema spp. compared to cases where L. passim infection was accompanied by a single Nosema spp. This may be due to the exhaustion of the bee's organism and complete loss of its defense capabilities. Therefore, it is subjected to the penetration of the third parasite L.passim. A similar relationship was observed by Ptaszyńska, Paleolog, \& Borsuk (2016) and Borsuk et al. (2013). The authors found that $N$. ceranae infection promoted the proliferation of yeasts in honey bee intestines. In our case, the invasion of three pathogens was intensified, perhaps due to the compromised immunity of the honeybees. N. ceranae (Antùnez et al., 2009) suppresses the immune system, which facilitates the penetration of other parasites into the bee's organism and additional deterioration. This in turn leads to the depopulation and extinction of bee colonies. From the etiological point of view, it will be important to establish which pathogen is the first to colonize the host in future studies. The role played by L. passim in honey bees colonies is still being debated, but there аге no doubts that this parasite compromises bee health. A steady increase in the mortality of bee colonies and lower levels of bee activity were reported by Chilean beekeepers (Arismendi et al., 2016). These losses were probably sustained due to the presence of $N$. ceranae in $18 \%$ of the studied apiaries, but L. passim was also detected in $90 \%$ of the analyzed samples (Rodríguez et al., 2012; Rodríguez et al., 2014). A similar study was conducted in Belgium by Ravoet et al. (2013), who identified C. mellificae as a new pathogen responsible for the collapse of bee colonies. 
In view of the general scarcity of epidemiological data about coinfections with Nosema spp. and L. passim in feral honey bees in other countries, further research is needed to confirm the effect of concurrent pathogenic infections on the decline of bee colonies. The role of L.passim and coinfections with other pathogens, including viral, bacterial and parasitic infections, in bee colonies should be investigated.

\section{ACKNOWLEDGMENT}

The project was financially co-supported by the Minister of Science and Higher Education under the program "Regional Initiative of Excellence" for 2019-2022, Project No. 010/RID/2018/19."

\section{REFERENCES}

Adl, S.M., Simpson, A.G., Farmer, M.A., Andersen, R.A., Anderson, O.R., Barta, J.R., ... Taylor, M.F. (2005). The new higher level classification of eukaryotes with emphasis on the taxonomy of protists. Journal of Eukaryotic Microbiology, 52(5), 399-451. http://doi. org/10.1111/j.1550-7408.2005.00053

Antúnez, K., Martín-Hernández, R.,Prieto, L., Meana, A., Zunino, P., Higes, M. (2009). Immune suppression in the honey bee (Apis mellifera) following infection by Nosema ceranae (Microsporidia). Environmental Microbiology, 77(9), 2284-2290. https://doi. org/10.1111/j.1462-2920.2009.01953.x

Arismendi, N., Bruna, A., Zapata N., \& Vargas, M. (2016). PCR-specific detection of recently described Lotmaria passim (Trypanosomatidae) in Chilean apiaries. Journal of Invertebrate Pathology, 134, 1-5. http://doi.org/10.1016/j.jip.2015.12.008

Banaszak, J. (2009). Pollinating insects (Hymenoptera: Apoidea, Apiformes) as an example of changes in fauna. Fragmenta Faunistica, 52(2), 105-123.

Barrett, J., Vardulaki, K.A., Conlon, C., Cooke, J., Daza-Ramirez, P., Evans, E.G.V., ... Viscoli, C. (2003). A Systematic Review of the Antifungal Effectiveness and Tolerability of Amphotericin B Formulations. Clinical Therapeutic, 25, 1295-1320.
Borsuk, G., Czerska, K., Olszewski, K., Strachecka, A., Paleolog, J., Chobotow, J. (2012). Aktualny stan wiedzy o Varroa destructor. Medycycna Weteryпагуjп, 68(10), 579-584.

Borsuk, G., Ptaszyńska, A., Olszewski, K., \& Paleolog, J. (2013) Impact of nosemosis on the intestinal yeast flora of honey bees. Medycyna Weterynaryjna, $69(12), 726-729$.

Chen, Y., Evans, J.D., Smith, I.B., \& Pettis, J.S. (2008). Nosema ceranae is a long-present and wide-spread microsporidian infection of the European honey bee (Apis mellifera) in the United States. Journal of Invertebrate Pathology, 972), 186-188. http://doi. org/10.1016/j.jip.2007.07.010

Cornman, R.S., Tarpy, D.R., Chen, Y., Jeffreys, L., Lopez, D., van Pettis, J.S., Engelsdorp, D., Evans J.D. (2012). Pathogen webs in collapsing honey bee colonies PLOS ONE, 7, e43562. https://doi.org/10.1371/journal.pone.0043562

Crane, E. (1999). The World History of Beekeeping and Honey Hunting. Gerald Duckworth \& Co. Ltd, London.

De la Rúa, P., Jaffé, R., Dall'Olio, R., Muñoz, I., Serrano, J. (2009). Biodiversity, conservation and current threats to European honey bees. Apidologie, 40(3), 263-284. http://doi.org/ 10.1051/apido/2009027

Engelsdorp, D., Evans, J. D., Saegerman, C., Mullin, C., Haubruge, E., Nguyen, B. K.,... Pettis, J. S. (2009). Colony collapse disorder: a descriptive study. PLoS ONE, 4(8), e6481. http://doi.org/10.1371/journal. pone.0006481

Evans, J.D., Schwarz, S., Chen, Y., Budge, G., Cornman, R., De la Rua, P., ... Pint, M.A. (2013). Standard methods for molecular research in Apis mellifera. Journal of Apicultural Research, 52(4), 1-53. https://doi. org/10.3896/IBRA.1.52.4.1

Gegear, J.R. (2005). Multicomponent floral signals elicit selective foraging in bumblebees. Naturwissenhaften, 92(6), 269-271. http://doi.org/10.1007/ s00114-005-0621-5 
Goulson, D., Nicholls, E., Botías, C., \& Rotheray, E.L. (2015). Bee declines driven by combined stress from parasites, pesticides, and lack of flowers. Science, 347, 1255957 http://doi.org/10.1126/science.1255957

Higes, M., Meana, A., Bartolomé, C., Botías, C., MartínHernández, R. (2013). Nosema ceranae(Microsporidia), a controversial $21^{\text {st }}$ century honey bee pathogen. Environmental Microbiology Reports, 5(1), 17-29. http://doi.org/10.1111/1758-2229.12024

Hubert, J., Bicianova, M., Ledvinka, O., Kamler, M., Lester, P..., Nesvorna, M., Kopecky, J., Erban, T. (2017). Changes in the bacteriome of honey bees associated with the parasite Varroa destructor, and pathogens Nosema and Lotmaria passim. Microbial Ecology, 73, 685-698.

Ilyasov, R.A., Kosarev, M.N., Neal, A., \& Yumaguzhin, F.G. (2015). Burzyan Wild-Hive Honeybee A. m. me/lifera in South Ural. Bee World, 92, 7-11. http://doi.org /10.1080/0005772×.2015.1047634

Langridge, D.F., \& McGhee, R.B. (1967). Crithidia mellificae n. sp. an acidophilic trypanosomatid of the honey bee Apis mellifera. Journal of Protozoology, 14(3), 485-487. https://doi.org/10.1111/j.1550-7408.1967. tb02033

Łopieńska-Biernat E., Sokół R., Michalczyk M., Żółtowska K., Stryiński R. (2017). Biochemical status of feral honey bees (Apis mellifera) infested with various pathogens. Journal of Apicultural Research, 56(5), 606-615. https://doi.org/10.1080/00218839 .2017 .1343020

Martin, S.I., Highfield, A.C., Brettell, L., Villalobos, E.M., Budge, G.E., Powell, M., Nikaido, S., Schroeder, D.C. (2012). Global honey bee viral landscape altered by a parasitic mite. Science, 336, 1304-1306. http://doi. org/10.1126/science.1220941.

Maslov, D.A.Votypka, J., Yurchenko, V., \& Lukes, J. (2013). Diversity and phylogeny of insect trypanosomatids: all that is hidden shall be revealed. Trends Parasitology, 29(1), 43-52. http://doi.org/10.1016/j. pt.2012.11.001
Michalczyk, M., Sokół, R., \& Koziatek, S. (2015). Evaluation of the effectiveness of selected treatments of Nosema spp. infection by the hemocytometric method and multiplex PCR. Acta Veterinaria Beograd, 66(1), 115-124. https://doi.org/10.1515/acve2016-0009

Michalczyk, M., \& Sokół, R. (2018). Estimation of the influence of selected products on co-infection with N. apis/N. ceranae in Apis mellifera using real-time PCR. Invertebrate Reproduction and Development. http://doi.org/10.1080/07924259.2018.1433726

Moritz, R.F.A., de Miranda, J., Fries, I., Le Conte, Y., Neumann, P., Paxton, R. (2010). Research strategies to improve honeybee health in Europe. Apidologie, 41, 227-242. http://doi.org/10.1051/apido/2010010

Nazzi, F., \& Le Conte, Y. (2016). Ecology of Varroa destructor, the Major Ectoparasite of the Western Honey Bee, Apis mellifera. Annual Review of Entomology, 61, 417-32. http://doi.org/10.1146/annurevento-010715-023731

Neumann, P., \& Carreck, N. (2010). Honey bee colony losses. Journal of Apicultural Research, 49(1), 1-6. https://doi.org/10.3896/IBRA.1.49.1.01

Oleksa, A., Gawroński, R., \& Tofilski, A. (2013). Rural avenues as a refuge for feral honey bee population. Journal of Insect Conservation, 17, 465-472. DOl: 10.1007/s10841-012-9528-6

Potts, S.G., Biesmeijer J.C., Kremen, C., Neumann, P., Schweiger, O., Kunin, W.E. (2010). Global pollinator declines: drivers and impacts. Trends Ecology. Evolution, 25(6), 345-353. http://doi.org/10.1016/j. tree.2010.01.007

Ptaszyńska, A., Paleolog, J., \& Borsuk, G. (2016). Nosema ceranae infection promotes proliferation of yeasts in honey bee intestines. PloS ONE, 17(10),116. https://doi.org/10.1371/journal.pone.0164477

Ptaszyńska, A., Borsuk, G., Mułenko, W., \& DemetrakiPaleolog, 」. (2017). Differentiation of Nosema apis and Nosema ceranae spores under Scanning Electron Microscopy. Journal of Apicultural Research, 53, 
537-544. https://doi.org/10.3896//BRA.1.53.5.02

Ptaszyńska, A., Gancarz, M., Hurd, P..., Borsuk, G., Wiącek, D., Nawrocka, A., ... Paleolog, J. (2018). Changes in the bioelement content of summer and winter western honeybees (Apis mellifera) induced by Nosema ceranae infection. Plos ONE, 13(5), 1-18. https://doi.org/10.3896/IBRA.1.53.5.02

Ravoet, J., Maharramov, J., Meeus, I., de Smet, L., Wenseleers, T., Smagghe, G., de Graaf, D.C. (2013). Comprehensive bee pathogen screening in Belgium reveals Crithidia mellificae as a new contributory factor to winter mortality PLoS ONE, 8, e72443 http://doi. org/10.1371/journal.pone.0072443

Retschnig, G., Williams, G.R., Schneeberger, A., \& Neumann, P. (2017). Cold Ambient Temperature Promotes Nosema spp. intensity in honey bees (Apis mellifera). Insects, 8(1), 1-20. http://doi.org/10.3390/ insects 8010020

Rodríguez, M., Vargas, M., Gerding, M., Navarro, H., Antúnez, K. (2012). Viral infection and Nosema ceranae in honey bees (Apis mellifera) in Chile. Journal of Apicultural Research, 57(3), 285-287. https://doi. org/10.3896/IBRA.1.51.3.12

Rodríguez, M., Vargas, M., Antúnez, K., Gerding, M., Castro, F.O., Zapata, N., Chilean, J. (2014). Prevalence and phylogenetic analysis of honey bee viruses in the Biobío Region of Chile and their association with other honey bee pathogens. Agricultural Research, 74(2), 170-177. http://dx.doi.org/10.4067/S071858392014000200007

Rosenkranz, P., Aumeier, P., \& Ziegelmann, B. (2010). Biology and control of Varroa destructor. Journal of Invertebrate Pathology, 103(1), 96-119. DOl: 10.1016/j.jip.2009.07.016.

Runcke, I C., Flenniken, M.L., Engel, J.C., Ruby, J.G., Ganem, D., Andino, R., DeRisi, J.L. (2011). Temporal analysis of the honey bee microbiome reveals four novel viruses and seasonal prevalence of known viruses, Nosema, and Crithidia. PLoS ONE, 6p. e20656 http:// doi.org/ 10.1371/journal.pone.0020656
Ruttner, F. (1988). Biogegraphy and Taxonomy of Honeybees. Springer-Verlag. ISBN 3-540-17781-7. https://doi.org/10.1002/mmnd.19890360109

Sammataro, D., Gerson, U., \& Needham, G. (2000). Рarasitic mites of honey bees: life history, implications, and impact. Annual Review of Entomology, 45, 519-548. http://doi.org/10.1146/annurev. ento.45.1.519

Schwarz, R.S., Bauchan, G.R., Murphy, C., Ravoet, J., de Graaf, D.C., Evans, J.D. (2015). Characterization of two species of Trypanosomatidae from the honey bee Apis mellifera. Crithidia mellificae Langridge and McGhee, and Lotmaria passim. Journal of Eukaryotic Microbiology, 62, 567-583, http://doi.org/10.1111/ jeu.12209

Seeley, T.D. (1985). Honeybee Ecology: A Study of Adaptation in Social Life. Princeton: Princeton University Press

Seeley, T.D. (2007). Honey bees of the Arnot Forest: a population of feral colonies persisting with Varroa destructor in the northeastern United States. Apidologie. 38, 19-29. http://doi.org/10.1051/apido:2006055

Sokół, R., \& Michalczyk, M. (2016). Detection of Nosema spp. in worker bees, pollen and bee bread during the honey flow season. Acta Veterinaria Bгпo, 85(3), 261-266. http://doi.org/10.2754/ avb201685030261

Stanimirovic, Z., Glavinic, U., Lakic, N., Radovic, D, Ristanic, M., Taric, E., Stevanovic, J. (2017). Efficacy of plant-derived formulation "Argus Ras" in Varroa destructor control. Acta Veterinaria Beograd, 671), 191-200.

Stevanovic, R.S. Schwarz, B. Vejnovic, J.D. Evans, R.E. Irwin, U. Glavinic, Z. Stanimirovic. (2016). Speciesspecific diagnostics of Apis mellifera trypanosomatids: a nine-year survey (2007-2015) for trypanosomatids and microsporidians in Serbian honey bees. Journal of Invertebrate Pathology, 139, 6-11. http:// doi.org/10.1016/j.jip.2016.07.001 
Sulborska, A., Horecka, B., Cebrat, M., Kowalczyk, M., Skrzypek, T.H., Kazimierczak, W., Trytek, M., Borsuk, G. (2019). Microsporidia Nosema spp. - obligate bee parasites are transmitted by air. Scientific Reports, 9, 14376. https://doi.org/10.1038/s41598-01950974-8

Tritschler, M., Retschnig, G., Yañez, O., Williams, G.R., Neumann, P. (2017). Host sharing by the honey bee parasites Lotmaria passim and Nosema ceranae. Ecology Evolution, 7(6), 1850-1857. doi: 10.1002/ ece3.2796

Webster, T.C., Pompe,r K.W., Hunt, G., Thacker, E.M., Jones, S.C. (2004). Nosema apis infection in worker and queen Apis mellifera. Apidologie. 35, 49-54. http://doi.org/10.1051/apido:2003063 van Dooremalen, C., Gerritsen, L., Cornelissen, B., van der Steen, J.J.M., van Langevelde, F., Blacquière, T. (2012). Winter survival of individual honey bees and honey bee colonies depends on level of Varroa destructor infestation. PLOS ONE. 74):e36285. http:// doi.org/ 10.1371/journal.pone.0036285

Vejnovic, B., Stevanovic, J., Schwarz, R.S., Aleksic, N., Mirilovic, M., Jovanovic, N.M., Stanimirovic, Z. (2018). Quantitative PCR assessment of Lotmaria passim in Apis mellifera colonies co-infected naturally with Nosema ceranae. Journal of Invertebrate Pathology, 157, 76-81. http://doi.org/10.1016/j.jip.2017.11.003 